\author{
Sheikh Md. Abdul Hakeem \\ Ph.D. Student, Portsmouth Business School, \\ Portsmouth University, \\ Portsmouth, England
}

Md Yusuf Hossein Khan, Ph.D. Researcher in Tourism, University of Algarve, Faro, Portugal; Assistant Professor, College of Tourism and Hospitality Management, IUBAT - International University of Business Agriculture and Technology, Dhaka, Bangladesh

\title{
URBAN TOURISM: THE PERSPECTIVE ON TOURISM IMPACTS IN CAMBRIDGE, UNITED KINGDOM
}

Tourism has become a modern global phenomenon and contributes to the development of the society in many possible ways. The visible impact of the tourism development not only involves the economic factors but also develop the environmental, cultural and social aspects of life and well-being. Matter of fact, because of this various benefits arising from the tourism development, it has been able to gain a very important and significant status in the community and many countries are recognising tourism as their priority in the economic development. Urban tourism is a concept within the tourism and it becomes one of the main functions of the cities and its importance is still growing. Urban tourism locations rich in historic features often serve as a suitable example of urban locations positioned to attract visitors to enjoy the historic and cultural experiences on offer. Focusing on Cambridge, a city in the United Kingdom this paper explored the concept of Urban Tourism with an emphasis on the characteristics and type of visitors to cities and the natural impacts of tourism and also focused on the costs and benefits of urban tourism in terms of economic, social, cultural and environmental considerations. Using different literature from various articles, books, research papers and case studies, this paper identifies if Cambridge is able to retain its culture and identity in spite of its popularity as a tourism destination. This paper presents the results of a theoretical analysis which showed that tourism impacts have largely been well managed in Cambridge and the city has been able to maintain the characteristics and original features of a heritage city. Preservation of architecture, a wide range of entertainment and cultural events, sports and leisure facilities are all well served. The results of this research can be useful in identifying the role of the public and private sector in urban tourism and their impact on local residents and aims to create awareness among organizations relating to the Urban tourism, local residents and government.

Keywords: community, culture, development, heritage, infrastructure, urban tourism.

Introduction. Nowadays, travel, tourism and hospitality industry is one of the fastest growing communities around the globe. For the earning good money and for successful results, there should be accomplished plan on maintaining travel and hospitality destinations at its best. Tourism plays a vital and significant role in increasing the popularity and economy condition of a country (Bynum, 2011). Tourism helps to expand the GDP of a particular country by expanding the popularity and historical significance of that particular tourism destination (Brayley, 2010). Tourism is the short-term movement of people to places they do not normally reside or work in (Cruz, 2006). The Tourism Industry is defined as a mass of organisations from different sectors supplying those activities termed tourism (Cooper 2011). Tourism is a very difficult subject to define as it covers many different economic sectors and diverse subjects (Gilbert 1990). Tourism is defined as being a combination of individuals, organisations, businesses as places delivering a travel experience (Cooper et al., 2008).

Hunziker and Krapf (1941) were the first to formally define tourism but the concept of urban tourism is 
fairly recent (Edwards, Griffin \& Hayllar, 2008). Ashworth (1989) first formally acknowledged the idea of urban tourism which formalised the theory on visitors travelling to cities for pleasure. Tourism operates alongside other businesses, commercial and social activities in urban locations and is closely linked with urban development. However due to this cross subject activity urban tourism was often overlooked until the early 1990s (Ritchie 2008). Tourism is now one of the most fastest growing industry for many countries and it plays very significant role for the development of the economy of a country. Hobson and Uysal, (2013) clarified that the tourism industry has nearly $43 \%$ contribution to the GDP of many countries. One of the recent studies shows that the significance of destination image, it discovered destination image has $45 \%$ impact for increasing the popularity of a tourist destination (Kastenholz, Eusebio and Carneiro, 2013). Urban tourism is playing its part regardless improving the destination image and it is now a must that local government and privet sector should have well managed plan to protect Urban destinations.

Urban tourism is therefore defined as being tourism in an urban area (Law, 2001). Urban tourist locations can be defined by their size (Cazes and Potier, 1967) and this can lead to a wide variety of locations being considered urban tourist destinations such as capital cities (e.g. Paris), industrial cities (e.g. Bradford), seaside resorts (e.g. Miami), cultural cities (e.g. Venice) and historic cities (e.g. Vienna or Cambridge).

Cities may differ in their size and their histories, but all have developed following growth in the socioeconomic environment of their respective nations. Tourism has offered an escape for many centuries to the middle class, and then to the working class during the modern-industrialisation era. In the post industrialist era, urban tourist destinations are packaged as places of pleasure, such as Atlantic City, or places of consumption in a new era of consumerism (Mullins 1991).

Urban tourism was classified by Judd and Fainstein (1999) into three main areas following major studies in the new subject by other academics:

- Tourism Urbanization - these are planned or unplanned tourist resorts which have been created (Mullins 1991).

- Converted Cities - Cities which have adapted to construct a tourist infrastructure for visitors

- Tourist-Historic Cities - these are locations rich in historic, culture and historic architecture which attract tourists to experience such features (Ashworth and Tunbridge, 1990)

Visitors to Urban Destinations. In the post industrialist environment, cities are now offered to be consumed by tourists much like any other product. Tourists may have different motivations to visit cities, such as for escapism, for authentic experiences, for business reasons, for personal discovery or a combination of these reasons.

A differentiation between travellers and tourists was made by Boorstin (1964) where the traveller is assumed to actively search for an individual experience and adventure when visiting locations. Tourists can be assumed to be more passive, seeking inauthenticity preferring their own expectations of foreign culture rather than an authentic experience (Sternberg 1997). This model is supported by MacCannell (1976) who argues that tourists are in search of authentic experiences but are not all able to find them because tourist offers are to some extent, inauthentic in their nature. Such a consideration of the types of tourist must be considered when marketing cities to tourists.

Other tourists may be considered less superficial, motivated by serious leisure (Stebbins 1996). Ooi (2002) proposes a model of a versatile tourist. This is a tourist who is experienced in travelling and able to select and organise their own agenda during their visit.

Cohen (1972) embarked on two major typological studies of on the sociology of tourists. In his study differentiations were made between tourists who are more likely to follow organised itinerary based trips and those who are more likely to self-organise their trip and immerse in the local culture and local population (e.g. The Drifter). The issue of Cambridge retaining its authenticity is important in this study.

Demand for Urban Tourism. The demand by tourists to an urban destination depends on the type of 
tourist. Some tourists are holidaymakers such as day visitors, attracted by leisure and recreation services on offer. Some authors argue in major capital and world-famous cities tourists can be residents (local and from the same country) travelling for business, health, education or visiting friends and relatives. Workers and Students can also be considered tourists who may visit a location based on the buildings, organisations and facilities established in a City such as Cambridge. The availability of such places to see, people to interact with, leisure and pleasure opportunities on offer will affect the demand from urban tourists (Kozak, 2002).

On an economic level, tourism levels are also affected by the price of visiting a city such as Cambridge, the exchange rate, the price of visiting alternative destinations and if there are any incentives or offers such as tax-free shopping or special events (e.g. the Olympic games). Demographics may also affect tourist demand, as tourists will be of a certain age, at a certain stage of their life, have a certain income and gender. For example, tourist destinations such as Ibiza are often a choice of holiday destination by 18-30-year-olds in search of nightlife, cheap drinks and pop music. Other tourist destinations may be of more interest to a retirement age tourist in search of a quieter, more sedate experience. Population demographics may also influence tourist demand as they will affect the numbers of visitors travelling to a destination for education (e.g. school age), work, resort cities (e.g. Las Vegas or Atlantic City for gambling by over 21 year olds), those interested in heritage cities and those interested in new destinations (e.g. new family theme parks).

Supply of Urban Tourism and its Marketing. In the post-industrialist era, modern cities have largely lost their manufacturing base, their industrial base and trade base so tourism provides a large incentive for economic success for cities. Urban tourism is also a product of social changes and modern city developments with the facilities, leisure, organisations and services on offer for other visitors. Strategic planning for tourism may take place by public and private bodies who decide to offer services for tourists to consume. Businesses hoping to capitalise on urban tourism may use typological models of tourists (Sharpley, 2000) to identify which types of tourists to attract and what services to create for these visitors.

In this model, there are experience consumers who are motivated by enjoyment and enjoying leisure. Others may be interested in consuming as play, by interacting with others in a group. Others may be interested in consuming as integration, such as a group of friends travelling together to enjoy a common experience for the first time together. The last group includes those tourists consuming as classification, who wish for example to say they have visited a certain city for status or other reasons of classification (Poon, 1993).

Marketing decisions on urban tourism are based on data generated from visitors' motivation and experiences in market research (e.g Surveys). Theories are then generated from this data in an inductive approach. Marketing decisions are made as to who to attract (i.e. visitor type), what market segment to target (e.g. historical and cultural tourists) and how to adapt their offering to attract that target market (e.g. advertising campaign in newspapers).

Tourist-Historic Cities and Heritage Tourism. Tourist-Historic Cities are often characterised by their architecture, the preservation of heritage sites and with strict control of new building development. The city in its entirety is often presented as an experience with its history and culture exaggerated. Other features of a culturally rich historic city, such as Venice, may include art exhibitions, music and theatre and a marketing campaign aimed to avoid the mass market, offering an experience rich in events and cultural offerings.

Visitor Impacts of Urban Tourism. Due to the wide nature of the tourism industry, the impacts of tourism are difficult to measure. One method of measuring the impact is using the Cambridge Model, for calculating the value of tourism to local authorities in the UK (The Economic Impact of Tourism in Cambridge 2010). The total tourism value for Cambridge is estimated at over £1.5bn (The Economic Impact of Tourism in Cambridge 2010). This figure includes total visitor spending and supplier and income induced spend on 
the tourism industry in Cambridge. It is of huge financial importance to the region. Figures for 2010 suggest direct employment from tourism hires 21,570 staff (The Economic Impact of Tourism in Cambridge 2010).

However, there are downsides to the economics of Cambridge and similar cities' tourist industries. It involves maintenance and management of the industry which uses public funds (e.g. marketing campaigns, tourist signage and infrastructure expenses). This can divert funds away from other local needs. It can also make property prices more expensive in the local area which will price out local businesses and residents.

The social benefits of tourism include more arts, entertainment, dining and cultural events in the community which are primarily established for tourists and visitors. The negative social effects include local residents feeling displaced, and a reliance on tourism for economic reasons rather than the organic and diversified development of a city (Harcombe, 1999).

There may also be environmental effects including pollution, noise, disturbances, congestion and abuse of public spaces and services. However, heritage-based tourism is usually incorporated with protective planning from authorities who focus on conservation of heritage sites, maintenance of natural and historic parts of the city and enhance the environment in a city. Larger cities are more able to withstand the saturation effects of tourism due to their size unless the heritage areas are overdeveloped without regulation. Smaller cities are less able to defend against saturation with their medieval streets, high level of heritage sites and lack of transport services on offer. This may cause social conflict with local residents who may be less tolerant of external visitors to their way of life in these historic cities. Cities may also suffer a loss of their natural culture with the gentrification of the area and local residents having to leave the area as they can no longer afford to live there anymore due to the success of tourism (Harcombe, 1999).

Classification of Heritage Sites. Each tourist perceives the destination and the experience offered by the destination in their very own special and individualised way, which is in the sum of their past life experience, education and attitudes - in other words, a whole series of personal characteristics. The focus of creating experience is for the individual and the fulfilment of their interest, needs and expectations relating to their personal experience (Morgan et al. 2011). Tourists will have a multiplicity of emotional, physical and cognitive reactions towards the heritage destination triggered within them during their visit, where they will experience a state of flow.

Cambridge as an Urban Tourism Destination. Cambridge is a city known worldwide for its educational institutions founded in 1209. Cambridge is a historic city with evidence of settlement during the Iron Age and beyond into the Roman era. The Kings College Chapel was built in 1446 by King Henry VI and is evidence of many medieval buildings in the City. The city is closely structured with many tight streets and developed around the River Cam. Today the city is still famous for its University and attracts visitors from around the world due to its celebrated educational status. The city also is a hub for high technology and modern businesses which attracts many business tourists. The city has a developed an urban tourist strategy from 2005 and is an example of a tourist-historic city in tourism studies (Maitland, 2005). In accordance with the classification of heritage sites from the table 1, Cambridge can be categorized as a national heritage site as well as a local heritage site.

Types of Attractions in Cambridge. The location of Cambridge's Tourist Information Centre seems strategically placed, on Peas Hill in the centre of Cambridge's historic centre. It is located yards away from the heart of Cambridge University, with several of its major colleges facing opposite the Centre. The architecture and narrow streets are classic characteristics of Historic Urban cities (Ashworth and Tunbridge, 1990). Cultural and leisure attractions are nearby with the Cambridge Arts Theatre and the Cambridge Corn Exchange, a historic building holding many cultural events such as comedy shows and other entertainment events. Museums are also located not too far from the Visitor Centre with zoology and archaeology on offer to visitors. 


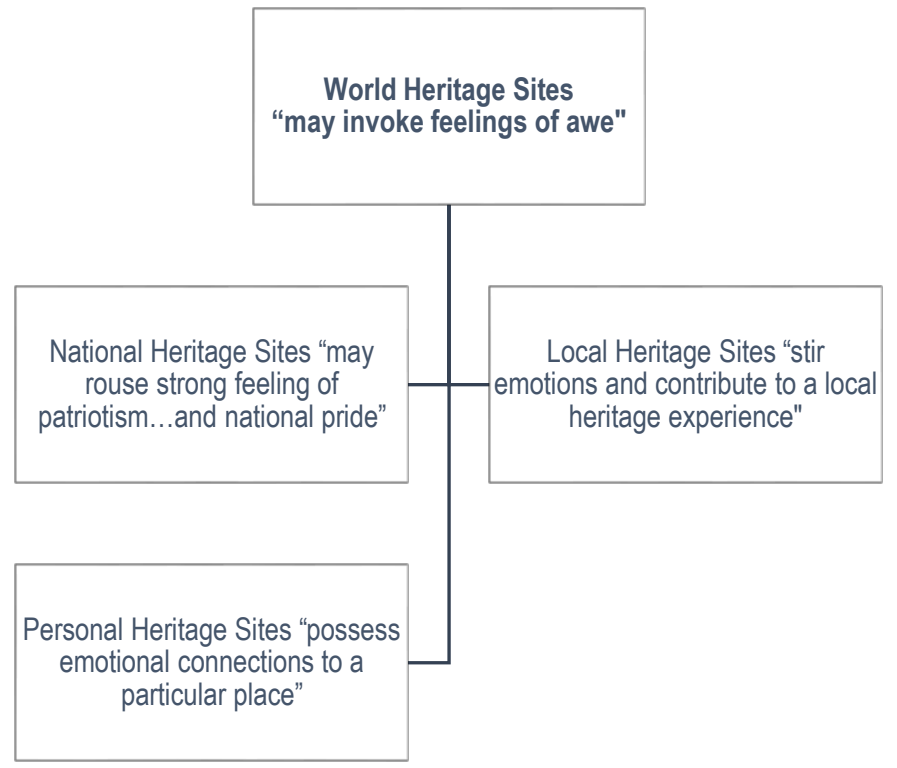

Figure 1 - Classification of Heritage Sites (Timothy 1997)

Even without any prior knowledge or planning, there is plenty to do and see in Cambridge. The Tourist Information Centre performs a major role in informing through literature, the website, staffs and advertising on other attractions on offer. This includes sport and leisure, nightlife and dining information and the offer of official guided tours. There is a wide range of sites to see, events to participate in and even tourist information beyond Cambridge on offer in the Centre and on the website.

The primary elements advertised to tourists and even secondary elements such as hotels and catering facilities, information on shopping facilities all meet the criteria set out in the Inner City Tourism Model (Jansen-Verbeke 1986). Tourism is well established in Cambridge, a strategy that started in 1978 (Maitland 2006). The City centre is designed for tourists with signage clearly marking out places to see and visit, signage back to the Tourist Information Centre and clean roads with a wide range of pedestrian access. There is a one-way road system in the City centre and pedestrian access seems to be prioritized. There is also a lack of city centre parking with a focus on using the Park and Ride bus scheme. This seems to favour use from tourists rather than locals.

Tourism Product. The Cambridge tourism market is a mature product with a supporting network of infrastructure for the visitor (e.g. Information Centre), local government with its implementation of pedestrian access, Park and Ride scheme and supporting parties proving services in entertainment and hospitality for the tourist. There are many adverts, many places to eat and drink and businesses supporting leisure in Cambridge. There are also official guided tours for the unplanned Tourist (Cohen 1972) and an amount of tourism support in other languages for foreign (speaking) visitors. Secondary elements of tourism also exist with boat rides and taxis helping tourists with information and pleasant service. These services can also be enjoyed by locals and the whole community can benefit from the safe and relaxed environment.

Characteristics of Visitors to Cambridge. Cambridge is dominated by its educational facilities and this invites many students and other visitors to the area. There are also several business parks with office facilities on the outskirts of the city. This is not advertised through the official Tourist Information Centre but the advice is given in literature and on the website for business visitors to the area who also enter 
Cambridge. Visitors seem to be national and international to the area and the historic architecture and heritage sites seem to bring a more mature demographic to Cambridge. Observations included visitors by coach on a tour to the many historic churches in Cambridge including Kings College Church founded in 1441, St. Benet's Church founded in 1020 and the Leper Chapel with its Norman Architecture. Cambridge is successful at attracting a wide range of type of visitor, however, we did not observe many family-type visitors or visitors driving around Cambridge by car. Most tourists are walking or using the official bus service.

Possible Tourism Impacts. As per the discussion and literature above tourism has been a success in Cambridge and brings important economic benefits that believe tourism is booming and the numbers of visitors increasing in Cambridge, which is supported by statistics from Cambridge City Council's figures (The Economic Impact of Tourism in Cambridge 2010). Tourism has brought greater income, more employment and a welcome economic boost despite the last few years of recession.

Local tourism has also brought a multiplier effect with more investment into Cambridge, with centralized support leading to greater infrastructure benefits, public transport spending, and investment into buildings and development like the new Grand Arcade Shopping centre. There is also a continual private investment into Cambridge's dining, entertainment and nightlife industry which attempts to profit from local tourism but also provides services to local residents and welcome employment opportunities.

Residents also feel supportive of the local government creating an environment for tourism growth with the implementation of Cambridge's Tourism Strategy Plan from 2001-2006. This plan was in coordination with national government and other local authorities (e.g. East Anglia Tourist Board). Residents feel this atmosphere has encouraged spending on more facilities such as security and extra CCTV which has made Cambridge safer. Residents also feel the historic aspect of Cambridge's tourism has protected the heritage status of its architecture and historic buildings such as King College Chapel. They also feel there are secondary benefits from tourism which gives a greater quality of life, such as shops and restaurants staying open later to cater for tourists.

The majority of visitors and travel to Cambridge is still education related. There is a bias towards the number of students in the city which may give an unbalanced demographic for the types of visitor to Cambridge. Many of the visitors who appreciate Cambridge's heritage sites are also more mature so there is a lack of attractions for younger residents in Cambridge makes no threat to the city heritage. The student bias of visitors also means there is a seasonal aspect to tourism commerce being much quieter during holidays when students return home. Some visitor sites are also closed to tourists during the exam period at the University.

The number of foreign students and foreign visitors has expanded the cultural opportunities from residents and allowed them to be more aware of the educational needs in the community.

Conclusion. Many believe that for over 30 years of tourism to Cambridge City has been a strategically managed programme and this has resulted in a successful sustainable tourism industry being cultivated which resulted in good revenues to the city tourism. There is no surprise that Cambridge City focuses heavily on the tourism industry and emphasises the importance of visitors to the city. Cambridge City's success has been in creating a sustainable industry whilst also retaining its main industry of higher education and developing high technology business parks and an infrastructure for commerce. This has been a successful diversification for generating income rather than a diversion of resources. Cambridge has been able to manage its heritage and architecture with government planning and policy. There has been a disruption to the level of development in the city due to its preference towards heritage and tourism which has annoyed some residents. Local transport by car and issues of parking are a major concern which the authorities have not adequately dealt with.

This paper concludes that tourism impacts have largely been well managed. Cambridge has been able to maintain the characteristics and original features of a heritage city. Preservation of architecture, a 
wide range of entertainment and cultural events, sports and leisure facilities are all well served. This is for both the local and visitor to enjoy. Future concerns as always relate to the integration and management of visitor numbers, their cultural and social integration into Cambridge's community and local issues of housing, transport burden and pollution levels. This will be a concern for Cambridge and local government to manage in the future but so far they have been able to manage such concerns with great economic benefit.

Ashworth, G. and Page, S.J., 2011. Urban tourism research: recent progress and current paradoxes. Tourism Management 32(1), pp 1-15.

Ashworth, G. and Tunbridge, J., 2000. The tourist-historic city. London: Belhaven

Ashworth, G.J. and Tunbridge, J.E., 2000. The Tourist-Historic City: Retrospect and Prospect of Managing the Heritage City. Amsterdam, New York: Pergamon.

Baade, R.A and Dye, R.F, 1990. The Impact of Stadium and Professional Sports on Metropolitan Area Development. Growth and Change, Volume 21, Issue 2, pp1-14.

Bowen, D., 2002. Research through Participant Observation in Tourism: A Creative Solution to the Measurement of Consumer Satisfaction/Dissatisfaction (CS/D) among Tourists, Journal of Travel Research August 2002 vol. 41 no1,.p p. 4-14.

Brayley, R. (2010). An analysis of destination attractiveness and the use of psychographics and demographics in segmentation of the within-state tourism market.

Bynum, W. (2011). Tourist attraction. Nature, 361(6414), pp.696-696

Cambridge Tourism Strategy, 2006, Cambridge City Council [online] Available at http://www.cambridge.gov.uk/ccm/navigation/leisure-and-entertainment/tourism [Accessed on 10 May 2018].

Cambridgeshire County Council, 2011. Cambridge City Annual demographic and socio-economic report 2011. Cambridge: Cambridgeshire County Council Publication.

Cohen, E., 1972, Towards a sociology of international tourism. Social Research, 39(1), pp.164-182.

Cohen, E., 1979, Rethinking the Sociology of Tourism. Annals of Tourism Research, 6(1), pp.18-35.

Hayllar, B., Griffin, T. And Edwards, D., 2008. City spaces- tourist places: urban tourism precincts. London: ButterworthHeinemann.

Harcombe, D.P.T., 1999. The Economic impacts of tourism, ABAC Journal, Vol. 19, no. 2. Bangkok: Assumption University. Hobson, J. and Uysal, M. (2013). Infrastructure: The Silent Crisis Facing the Future of Tourism. Journal of Hospitality \& Tourism Research, 17(1), 209-215.

Judd, D.R. and Fainstein, S.S. 1999. The Tourist City. New Haven, Conn., London: Yale University Press.

Kastenholz, E. Eusebio, C. and Carneiro, M. (2013). Studying factors influencing repeat visitation of cultural tourists. Journal of

Vacation Marketing, 19(4), 343-358.

Kozak, M., 2002. Destination benchmarking. Annals of Tourism Research. 29(2), pp. 497-519.

Law, C.M., 2001. Urban Tourism - The Visitor Economy and the Growth of Large Cities. London: Continuum.

Morgan, N., Pritchard, A. and Pride, R., 2011. Destination brands: managing place reputation. 3rd ed. Oxford: ButterworthHeinemann. 706.

Ooi, C.S., 2002. Contrasting strategies: tourism in Denmark and Singapore, Annals of Tourism Research, Vol. 29, No. 3. pp.689-

Page, S., 1995. Urban Tourism. London: Routledge

Page, S. And Connell, J. 2009. Tourism: A Modern Synthesis. Chapter 21: Urban Tourism, pp. 470-493. London: Cengage Learning.

Loftman , P. and Nevin, B., 1996. Going for growth: prestige projects in three British cities, Urban Studies. 33(6), pp.991-1019.

Loftman, P. and Nevin, B., 1995. Prestige projects and urban regeneration in the 1980s and 1990s: a review of the benefits and

limitations, Planning Practice and Research. 10(3-4), pp.299-315.

Poon, A., 1993. Tourism, Technology and Competitive Strategies, Wallingford: CABI Publishing.

Selby, M., 2004. Understanding Urban Tourism: Image Culture and Experience. London: I.B. Tauris.

Timothy, D. J., 1997. Tourism and the personal heritage experience. Annals of Tourism Research, 24 (3), 751-754

Vinuesa, M.A.T. and Torralba, L.T., 2010, Historic Cities and Tourism: Functional Dynamics and Urban Policy, The Open Urban Studies Journal, 2010, 3, pp.47-57

Visit Cambridge, 2012, Cambridge City Council [online] Available at: http://www.visitcambridge.org/visitor-information/touristinformation-centre [Accessed on 12 June 2018]. 
Ш. Мд. А. Хакім, Портсмутська Бізнес-школа, Портсмутський Університет (Портсмут, Англія);

Мд. Ю. Х. Хан, Університет Алгарве, (Португалія); Коледж готельно-ресторанної справи та туризму, Міжнародний університет аграрного бізнесу (Дакка, Бангладеш).

Міський туризм: перспективи впливу туризму на розвиток міста Кембридж (Великобританія)

В умовах сучасних глобалізаційних та євроінтеграційних трансформацій туризм стає однією із найбільш швидкозростаючих галузей економіки. Це пов'язано не лише з економічними чинниками функиіонування суспільства, але й з екологічними, культурними та соціальними аспектами. У зв'язку з цим на сьогоднішній день більшістю країн світу туризм визнаний пріоритетним напрямом соціально-економічного розвитку краӥни. Автори розглядають розвиток міського туризму як ключовий напрям популяризації історичної та культурної спадщини міста серед туристів. В роботі на прикладі міста Кембридж (Великобританія) досліджено концепцію міського туризму, яка орієнтована на задоволення індивідуальних потреб туристів. При цьому запропоновано враховувати наслідки впливу туризму на навколишне природне середовище. У дослідженні систематизовано переваги та недоліки розвитку міського туризму з економічної, соціальної, культурної та екологічної точки зору. Автори зазначають необхідність пошуку шляхів вирішення екологічних проблем, пов'язаних зі стрімким розвитком туристичної галузі. у роботі досліджено потенціал міста Кембридж (Великобританія) до збереження своєї культурної спадщини та індивідуальної унікальності, з урахуванням його зростаючої популярності як туристичного напрямку. Автори зазначають, що високий рівень популярності міста пояснюється його унікальною архітектурою та привабливою студентською інфраструктурою, наявністю широкого спектру спортивних та культурно-розважальних заходів, програм, розвитком інноваційно-технологічних парків, ділових осередків та торговельної інфраструктури тощо. Результати цього дослідження можуть бути використані з метою визначення ролі громадськості та приватного сектору економіки в розвитку міського туризму, оцінки ступеня його впливу на показники розвиту міст та країн в цілому.

Ключові слова: громада, культура, розвиток, спадщина, інфрраструктура, міський туризм. 